\title{
Screening Rice Genotypes for Brown Spot Disease Resistance
}

Arati Dhungana, Chiranjibi Puri, Kabita Shah, and Sirjana Yogi, Tribhuvan University, Institute of Agriculture and Animal Science, Prithu Technical College, Dang, Nepal, Durga Prasad Dhakal, Tribhuvan University, Institute of Agriculture and Animal Science, Lamjung Campus, Lamjung, Nepal, Basistha Acharya, Nepal Agricultural Research Council, DOAR, Province 5, Khajura, Banke, Nepal, and Jiban Shrestha, Nepal Agricultural Research Council, National Plant Breeding and Genetics Research Center, Khumaltar, Lalitpur, Nepal https://doi.org/10.52543/tjpp.15.2.1

\section{ABSTRACT \\ Dhungana, A., Puri, C., Shah, K., Yogi, S., Dhakal, D.P., Acharya, B., and Shrestha, J. 2020. Screening rice genotypes for brown spot disease resistance. Tunisian Journal of Plant Protection 15 (2): 29-39.}

A field experiment was conducted to screen 20 rice genotypes against brown spot disease caused by Bipolaris oryzae under natural epiphytotic field conditions at Bangaun, Dang, Nepal, from June 2018 to March 2019. The experiment was carried out in a randomized complete block design with 3 replications. Sawa Mansuli was taken as susceptible check and Sabitri as a resistant check in the experiment. Disease assessment was done by calculating disease severity and Area Under the Disease Progress Curve (AUDPC). Among the evaluated genotypes, disease severity and AUDPC varied in the field experiments. Rice genotypes showed the resistance to highly susceptible reactions based on AUDPC value which ranged from 88.51 to 260.65. Among the evalauted rice genotypes in the field experiment, the highest mean AUDPC value was recorded with Basmati (260.65) followed by Radha-13 (172.80) and the lowest was recorded with Kathe Jhinuwa (88.51). Similarly, the highest severity rate was recorded with Basmati (25.91) followed by Radha-13 (21.00) and Tilki (20.75) and the lowest was recorded with Kathe Jhinuwa (11.03) which was at par with Radha-4 (11.11) followed by Sukhadhan1 (12.02) and Sabitri (12.06). The highest grain yield was recorded with Sarju-52 (4.32 t/ha) followed by Sabitri (4.19 t/ha). Grain yield was negatively correlated with mean AUDPC by $14.77 \%$. Kathe Jhinuwa, Radha-4, and Sabitri can be used for higher grain yield purposes under similar field conditions and also can be utilized as the source of resistance in a plant breeding program.

Keywords: AUDPC, Bipolaris oryzae, brown spot, disease resistance, grain yield, Oryza sativa, severity

Rice (Oryza sativa L.) is the first staple food grain crop of Nepal and has a significant role in the food security of the Nepalese people. The productivity of rice is very low in Nepal compared to the

Corresponding author: Arati Dhungana

Email: arati66dhungana@gmail.com

Accepted for publication 17 September 2020 potential and attainable yield and yields obtained in neighboring countries. Among the fungal diseases of rice, brown spot disease, caused by Bipolaris oryzae (syn. Dreschslera oryzae, Helmintho-sporium oryzae) has become the emerging and major threat for yield decline. Brown spot has been widely reported in South-East Asian countries (Reddy et al. 2010). On an average, the disease causes $10 \%$ yield loss across all lowland rice production in South and Southeast Asia (Savary et al. 2005). In 
India, brown spot was recorded to reduce tiller number and also reduce the yield of 19.2-58.8\% (Chattopadhyay et al. 1975). The disease is also known as poor rice farmer's disease because it occurs mostly in deficient and poor soils (Zadoks 2002). The pathogen infects coleoptiles, leaves, leaf sheaths, panicle branches, glumes, and spikelets (Mew and Gonzales 2002). The use of resistant cultivars is the most economic and environmentally friendly method for the management of the disease (Haq et al. 2002), but the resistance is very scarce and not stable due to the appearance of new or more virulent races of the pathogens (Katasntones et al. 2007).
Therefore, the resistance level for each rice genotype has to be updated each year. Cultivation of resistant cultivars can be an eco-friendly and sustainable management strategy for brown spot disease control in rice. The current study was conducted to evaluate resistance of some popular rice genotypes among farmers of Dang district against brown spot disease.

\section{MATERIALS AND METHODS Rice genotypes.}

A total of 20 rice genotypes were collected from different sources as shown in Table 1. Sawa Mansuli was taken as a susceptible check and Sabitri as a resistant check.

Table 1. Source and origin of rice genotypes used in the experiment

\begin{tabular}{|c|c|c|c|}
\hline SN & Rice genotype & Parentage & Source \\
\hline 1 & Sukhadhan-1 (IR74371-46-1-1) & Rarem/2*IR55419-04 & $\begin{array}{l}\text { Phulbari, Rampur, } \\
\text { Chitwan }\end{array}$ \\
\hline 2 & Sukhadhan-2 (IR74371-54-1-1) & $\begin{array}{l}\text { IR55419-4/Way Rarem/IR55419- } \\
4\end{array}$ & $\begin{array}{l}\text { Phulbari, Rampur, } \\
\text { Chitwan }\end{array}$ \\
\hline 3 & Sukhadhan-3 (IR74371-70-1-1) & IR55419-04*2/Way Rarem & $\begin{array}{l}\text { Phulbari, Rampur, } \\
\text { Chitwan }\end{array}$ \\
\hline 4 & Sukhadhan-4 (IR 87707-446-B-B-B) & IR5657-33-2-1/IR2061-465-1-5-5 & $\begin{array}{l}\text { Phulbari, Rampur, } \\
\text { Chitwan }\end{array}$ \\
\hline 5 & Sukhadhan-5 (IR 83388-B-B-108-3) & IR8383B-B-108 & $\begin{array}{l}\text { Phulbari, Rampur, } \\
\text { Chitwan }\end{array}$ \\
\hline 6 & Sabitri (IR2071-124-6-4) & IR1561/IR1737// CR94-13 & RARS, Khajura, Banke \\
\hline 7 & Chaharang Sub-1/ IR09F436 & IRRI 149, Ciherang & RARS, Khajura, Banke \\
\hline 8 & Sawa Mansuli & - & RARS, Khajura, Banke \\
\hline 9 & Hardinath-3 & - & RARS, Khajura, Banke \\
\hline 10 & Radha-13 & - & RARS, Khajura, Banke \\
\hline 11 & Sarju-52 & $\mathrm{T}(\mathrm{N}) 1 /$ Kashi & Agro-vets of Dang \\
\hline 12 & Bindeshwari & $\mathrm{TN} 1 / \mathrm{Co} 29$ & Agro-vets of Dang \\
\hline 13 & Ramdhan & - & RARS, Khajura, Banke \\
\hline 14 & Anadi & Local Landrace & $\begin{array}{l}\text { Phulbari, Rampur, } \\
\text { Chitwan }\end{array}$ \\
\hline 15 & Tilki & Local Landrace & Farmer from Dang \\
\hline 16 & Basmati & Local Landrace & $\begin{array}{l}\text { Phulbari, } \\
\text { Chitwan }\end{array}$ \\
\hline 17 & Kathe Jhinuwa & Local Landrace & $\begin{array}{l}\text { Phulbari, } \\
\text { Chitwan }\end{array}$ \\
\hline 18 & Sunaulo Sugandha & $\begin{array}{l}\text { Pusa Basmati-1 (irradiated with } \gamma \text { - } \\
\text { radiation) *Unknown parents }\end{array}$ & RARS, Khajura, Banke \\
\hline 19 & Radha-4 & BG34-8/IR2071-635-1 & RARS, Khajura, Banke \\
\hline 20 & Local Mansuli & Local Landrace & Farmer from Dang \\
\hline
\end{tabular}

\section{Experimental site.}

The field experiment was conducted at the research field of Prithu
Technical College, Bangaun, Dang, Nepal which is located at $27^{\circ} 52^{\prime} 08^{\prime \prime} \mathrm{N}$ Latitude, 82 $32^{\prime} 42^{\prime \prime}$ E Longitude and 
$629.00 \mathrm{~m}$ above sea level at the Province number 5 of Nepal. The maximum and the minimum temperature recorded throughout the experiment was $34.28^{\circ} \mathrm{C}$ in July and $25.26^{\circ} \mathrm{C}$ in November with relative humidity ranging from $45.31 \%$ to $88.32 \%$. Maximum monthly rainfall recorded was $31.05 \mathrm{~mm}$. According to laboratory analyses of Prithu Technical College, the soil of the experimental plot was found to be silt loam having $\mathrm{pH}$ 6.67, total nitrogen $0.10 \%$, available phosphorus $45 \mathrm{~kg} / \mathrm{ha}$ and potassium $190.78 \mathrm{~kg} / \mathrm{ha}$.

\section{Nursery bed preparation and sowing.}

Nursery bed was prepared closer to the main field. Individual genotypes were provided with $1 \mathrm{~m}^{2}$ bed area in each replication. The seeds were soaked overnight in water for sowing the next day. Individual plots were divided into 10 rows of seed each $10 \mathrm{~cm}$ apart. Line sowing was practiced, and seeding was done on $21^{\text {st }}$ June at $40 \mathrm{~kg} \mathrm{ha}^{-}$ ${ }^{1}$ in a wet bed.

\section{Main field preparation and transplantation.}

The land was thoroughly ploughed and levelled. It was watered properly, and the experimental design was set up. The seedlings were allowed to remain in the bed for 21 days, then seedlings from individual plots were collected separately and transplanted to the main field spaced by $15 \mathrm{~cm}$ between plants and $20 \mathrm{~cm}$ between rows. Seedlings were transplanted according to the randomized complete block design (RCBD) with 20 treatments (genotypes used as treatments) and 3 replications during summer season (June to November, 2018/19) under rainfed condition. The individual plot size was $4.8 \mathrm{~m}^{2}$. Three seedlings were maintained per hill. Cultural practices were done as recommended for rice cultivation. Chemical fertilizers were applied at the rate of $100 \mathrm{~kg} \mathrm{~N}, 30 \mathrm{~kg} \mathrm{P} \mathrm{O}_{5}$ and $30 \mathrm{~kg}$ $\mathrm{K}_{2} \mathrm{O}$ per ha which was given through Urea, DAP, and Potash respectively.

\section{Disease assessment.}

Ten hills were selected randomly for each genotype of each plot and tagged for disease scoring, which was done 5 times at 8 days' interval starting from 44 days after transplanting. Disease rating scale of 0-9 (IRRI 2002) (Table 2) based on infected leaf area was used to estimate visually disease severity.

Table 2. Disease scoring scale of brown spot in rice as described by IRRI (2002)

\begin{tabular}{l|l}
\hline Score & \multicolumn{1}{|c}{$\begin{array}{c}\text { Infection } \\
\text { rate (\%) }\end{array}$} \\
\hline $\mathbf{0}$ & No infection \\
$\mathbf{1}$ & $<1$ \\
$\mathbf{2}$ & $1-3$ \\
$\mathbf{3}$ & $4-5$ \\
$\mathbf{4}$ & $6-10$ \\
$\mathbf{5}$ & $11-15$ \\
$\mathbf{6}$ & $16-25$ \\
$\mathbf{7}$ & $26-50$ \\
$\mathbf{8}$ & $51-75$ \\
$\mathbf{9}$ & $76-100$ \\
\hline
\end{tabular}

Disease severity $(\%)=\frac{\text { Sum of all numerical rating }}{\text { Total number of samples observed } \times \text { Maximum rating }} \times 100$ 
Disease severity was calculated per plant and mean severity was computed per plot as described by Galanihe et al. (2004). AUDPC values were computed, from the disease severity values using the formula given by Das et al. (1992) and Shrestha et al. (2019):

AUDPC $=\sum_{i=1}^{n-1}\left[\left(\frac{Y_{i}+Y_{i+1}}{2}\right) \times\left(t_{i+1}-t_{i}\right)\right]$ where, $\mathrm{Y}=$ disease scored on first date, $\mathrm{t}=$ date on which the disease was scored, $\mathrm{n}=$ number of dates on which disease was scored.

\section{Resistance of genotypes.}

The genotypes should be divided into five groups based on the AUDPC value (Table 3 ).

Table 3. Intervals of AUDPC values used to classify resistance level of rice genotypes

\begin{tabular}{l|ll}
\hline Mean AUDPC & Resistance category & Code \\
\hline $\mathbf{5 0}$ & Highly resistant & HR \\
$\mathbf{5 1 - 1 0 0}$ & Resistant & R \\
$\mathbf{1 0 1 - 1 5 0}$ & Moderately resistant & MR \\
$\mathbf{1 5 1 - 2 0 0}$ & Susceptible & S \\
$\mathbf{2 0 0}$ & Highly susceptible & HS \\
\hline
\end{tabular}

As described by Shrestha et al. (2020), the $12 \%$ moisture level was maintained to final grain yield by using following formula: Grain yield $(\mathrm{kg} / \mathrm{ha})=$ $(100-\mathrm{MC}) \times$ Plot yield $(\mathrm{kg}) \times 10000$ $(100-12) \times$ Plot area

where, $\mathrm{MC}=$ moisture content of grain $(\%)$.

\section{Data analysis.}

Data entry and processing were carried out using MS-Excel 2007 program. The recorded data were subjected to the analysis of variance and mean separation test was done using Duncan's multiple range tests (Gomez and Gomez 1984). Data analysis was done using $\mathrm{R}$ studio 3.5.3 and Agricolae version 1.3-0 package.
RESULTS genotypes.

Resistance level of rice

The result showed that there was a significant difference among rice genotypes in terms of mean AUDPC value $(P \leq 0.01)$ (Table 4). AUDPC values were highly variable due to difference in susceptibility of genotypes to the pathogen. The genotypes Basmati and Radha-13 showed the highest mean AUDPC value and the genotypes Kathe Jhinuwa, Radha-4 and Sabitri showed the lowest mean AUDPC values.

Mean AUDPC values categorized rice genotypes into four groups namely: resistant, moderately resistant, susceptible and highly susceptible. None of the tested genotypes was highly resistant according to the standard disease rating scale given by IRRI. 
Table 4. Resistant and susceptible categories of different rice genotypes towards brown spot disease, based on mean AUDPC values, at Bangaun, Dang in 2018/19

\begin{tabular}{|c|c|c|c|}
\hline SN & Genotype & $\begin{array}{c}\text { Mean } \\
\text { AUDPC }\end{array}$ & Code \\
\hline 1 & Basmati & $260.65^{\mathrm{a}}$ & Highly susceptible \\
\hline 2 & Radha-13 & $172.80^{\mathrm{b}}$ & \multirow{5}{*}{ Susceptible } \\
\hline 3 & Tilki & $161.36^{\mathrm{c}}$ & \\
\hline 4 & $\begin{array}{l}\text { Sunaulo } \\
\text { Sugandha }\end{array}$ & $155.35^{\mathrm{c}}$ & \\
\hline 5 & Sawa Mansuli & $153.70^{\mathrm{c}}$ & \\
\hline 6 & Hardinath-3 & $152.56^{\mathrm{c}}$ & \\
\hline 7 & Local Mansuli & $130.50^{\mathrm{de}}$ & \multirow{9}{*}{$\begin{array}{l}\text { Moderately } \\
\text { resistant }\end{array}$} \\
\hline 8 & Sukhadhan-5 & $139.64^{\mathrm{d}}$ & \\
\hline 9 & Ramdhan & $124.62^{\mathrm{ef}}$ & \\
\hline 10 & Anadi & $122.28^{\mathrm{efg}}$ & \\
\hline 11 & $\begin{array}{l}\text { Cheharang Sub- } \\
1\end{array}$ & $120.17^{\mathrm{fg}}$ & \\
\hline 12 & Sukhadhan-2 & $116.03^{\mathrm{fg}}$ & \\
\hline 13 & Sukhadhan-4 & $113.06^{\mathrm{gh}}$ & \\
\hline 14 & Sukhadhan-3 & $105.13^{\mathrm{hi}}$ & \\
\hline 15 & Sukhadhan-1 & $101.98^{\mathrm{ij}}$ & \\
\hline 16 & Bindeshwari & $95.57^{\mathrm{ijk}}$ & \multirow{5}{*}{ Resistant } \\
\hline 17 & Sarju-52 & $95.37^{\mathrm{ijk}}$ & \\
\hline 18 & Sabitri & $91.42^{\mathrm{k}}$ & \\
\hline 19 & Radha-4 & $88.88^{\mathrm{k}}$ & \\
\hline 20 & Kathe Jhinuwa & $88.51^{\mathrm{k}}$ & \\
\hline & Mean & \multicolumn{2}{|r|}{129.479} \\
\hline & $\operatorname{SEM}( \pm)$ & \multicolumn{2}{|r|}{8.9334} \\
\hline & $\mathrm{CV}(\%)$ & \multicolumn{2}{|r|}{3.76} \\
\hline & LSD (0.05) & \multicolumn{2}{|r|}{8.05} \\
\hline
\end{tabular}

CV: Coefficient of variance, LSD: Least significant difference, SEM ( \pm ): Standard error of mean. Means values of AUDPC followed by the same letters in a column are not significantly different $(P<0.05)$.

\section{Disease evolution with time.}

Initially, the differences in brown spot severity were slightly pronounced among the rice genotypes. Over time, the disease progressed faster in Basmati, Radha-13, Tilki, Sumaulo Sugandha and Sawa Mansuli compared to the remaining genotypes having a slow rate of disease progression such as Kathe Jhinuwa, Radha-4 and Sabitri (Fig. 1). Kathe Jhinuwa had a much slower rate of disease progression than that of Sabitri and Radha4. 


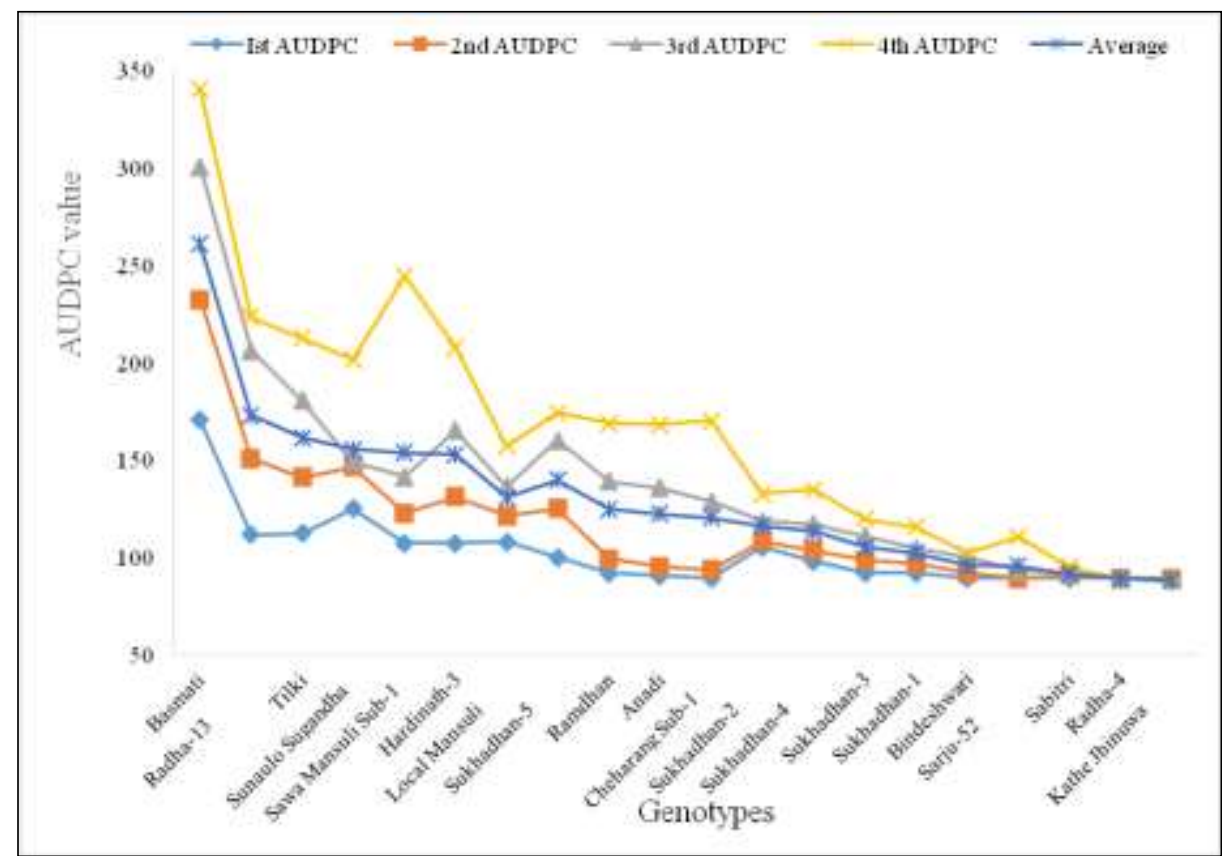

Fig. 1. Evolution of AUDPC with time of brown spot disease in rice genotypes at Bangaun, Dang in 2018/19.

Final disease severity, grain yield and thousand grain weight.

The rice genotypes varied significantly in yield and yield attributes $(\mathrm{P} \leq 0.001)$ (Table 5). The maximum grain yield was recorded in Sarju-52 (4.32 t/ha) followed by Sabitri (4.19 t/ha), Radha-13 (3.55 t/ha) and Bindeshwari (3.49 t/ha). The minimum grain yield was recorded in Tilki $(0.46$ t/ha), Anadi (0.66 t/ha) and Basmati (0.96 t/ha). Basmati and Tilki had the lowest grain yield with the highest disease severity while Radha-13 had grain yield similar to resistant genotype Sabitri, despite the highest disease severity.

\section{Regression analysis.}

There was significant negative linear relationship between the mean AUDPC and grain yield at $(P \leq 0.05)$ (Fig. 2) $\left(\mathrm{R}^{2}=0.15\right.$, may be not significant). According to the coefficient of determination, about $14.77 \%$ (it is low, but there is a tendency to) variation in grain yield was due to mean AUDPC. Higher temperature combined with high disease severity in the field affects the grain filling that ultimately causes a reduction in 1000-grain weight and yield (Duveiller et al. 2005). 
Table 5. Final disease severity, grain yield and thousand grains weight of rice genotypes grown in field at Bangaun, Dang in 2018/19

\begin{tabular}{|c|c|c|c|c|}
\hline SN & Genotype & $\begin{array}{c}\text { Final } \\
\text { disease } \\
\text { severity }(\%)\end{array}$ & $\begin{array}{c}1000 \\
\text { grain } \\
\text { weight }\end{array}$ & $\begin{array}{c}\text { Grain } \\
\text { yield } \\
\text { (t/ha) }\end{array}$ \\
\hline 1 & Basmati & $25.91^{\mathrm{a}}$ & $30.33^{\mathrm{abc}}$ & $0.96^{\mathrm{h}}$ \\
\hline 2 & Radha-13 & $21.00^{\mathrm{b}}$ & $25.33^{\mathrm{de}}$ & $3.55^{\mathrm{b}}$ \\
\hline 3 & Tilki & $20.75^{b}$ & $15.67^{\mathrm{f}}$ & $0.46^{j}$ \\
\hline 4 & Hardinath-3 & $20.52^{\mathrm{b}}$ & $30.00^{\mathrm{abc}}$ & $3.43^{b}$ \\
\hline 5 & $\begin{array}{l}\text { Sunaulo } \\
\text { Sugandha }\end{array}$ & $20.06^{\mathrm{b}}$ & $28.00^{\text {bcd }}$ & $3.00^{\mathrm{c}}$ \\
\hline 6 & Sawa Mansuli & $18.73^{\mathrm{bc}}$ & $15.67^{\mathrm{f}}$ & $1.62^{\mathrm{g}}$ \\
\hline 7 & Sukhadhan-5 & $16.06^{\mathrm{cd}}$ & $30.00^{\mathrm{abc}}$ & $2.03^{\text {ef }}$ \\
\hline 8 & Local Mansuli & $15.96^{\text {cde }}$ & $27.66^{\mathrm{cd}}$ & $2.65^{\mathrm{d}}$ \\
\hline 9 & Cheharang Sub-1 & $15.46^{\text {cdef }}$ & $32.00^{\mathrm{a}}$ & $2.24^{\mathrm{ef}}$ \\
\hline 10 & Anadi & $14.81^{\text {cdefg }}$ & $25.67^{\text {de }}$ & $0.66^{\mathrm{hi}}$ \\
\hline 11 & Sukhadhan-3 & $14.35^{\operatorname{defg}}$ & $30.00^{\mathrm{abc}}$ & $2.79^{\mathrm{cd}}$ \\
\hline 12 & Sukhadhan-2 & $14.34^{\mathrm{defg}}$ & $31.00^{\mathrm{ab}}$ & $2.74^{\mathrm{cd}}$ \\
\hline 13 & Ramdhan & $13.68^{\text {defg }}$ & $31.67^{\mathrm{a}}$ & $2.02^{\mathrm{ef}}$ \\
\hline 14 & Sukhadhan-4 & $13.68^{\text {defg }}$ & $29.33^{\mathrm{abc}}$ & $1.95^{\mathrm{f}}$ \\
\hline 15 & Sarju-52 & $12.55^{\text {defg }}$ & $29.67^{\mathrm{abc}}$ & $4.32^{\mathrm{a}}$ \\
\hline 16 & Bindeshwari & $12.20^{\text {defg }}$ & $28.33^{\mathrm{bcd}}$ & $3.49^{b}$ \\
\hline 17 & Sabitri & $12.06^{\mathrm{efg}}$ & $22.67^{\mathrm{e}}$ & $4.19^{\mathrm{a}}$ \\
\hline 18 & Sukhadhan-1 & $12.02^{\mathrm{efg}}$ & $27.66^{\mathrm{cd}}$ & $3.45^{\mathrm{b}}$ \\
\hline 19 & Radha-4 & $11.11^{\mathrm{g}}$ & $32.00^{\mathrm{a}}$ & $2.86^{\mathrm{cd}}$ \\
\hline 20 & Kathe Jhinuwa & $11.03^{\mathrm{g}}$ & $27.33^{\mathrm{cd}}$ & $2.29^{\mathrm{e}}$ \\
\hline & Mean & 15.814 & 27.4995 & 2.535 \\
\hline & SEM ( \pm$)$ & 0.9810095 & 1.108519 & 0.2395006 \\
\hline & $\mathrm{CV}(\%)$ & 13.28 & 6.069 & 7.17 \\
\hline & LSD (0.05) & 3.47 & 2.75 & 0.28 \\
\hline
\end{tabular}

CV: Coefficient of variance, LSD: Least significant difference,

SEM ( \pm ): Standard error of mean. Mean values of disease severity, grain yield and thousand grain weight followed by the same letters in a column are not significantly different $(P<0.05)$. 


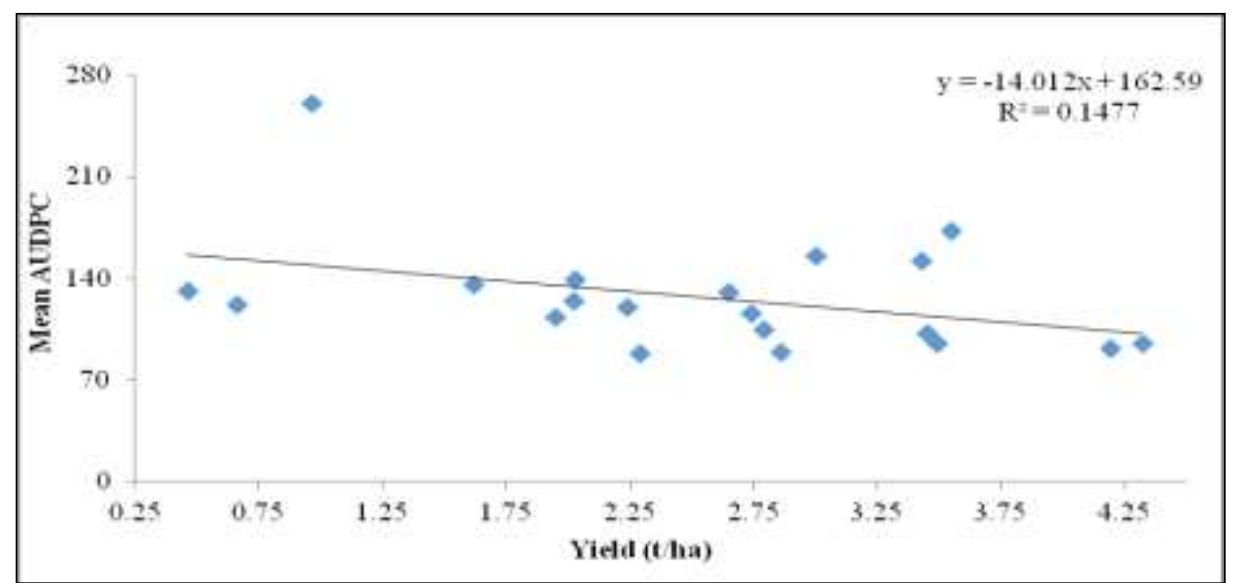

Fig. 2. Estimated linear relationship between mean AUDPC and grain yield (t/ha) at Bangaun, Dang in 2018/19.

\section{DISCUSSION}

\section{Area under disease progress curve (AUDPC) in rice genotypes.}

This study was carried out to assess the response of different rice genotypes against $B$. oryzae and possible use of these genotypes in breeding programs to manage brown leaf spot disease. Here, Sawa Mansuli was taken as susceptible check and Sabitri as resistant. AUDPC value was highly variable in the genotypes due to differences in susceptibility to the pathogen. Similar findings were also reported by Magar (2015) and Aryal et al. (2016) and also in other disease systems (Al-Maaroof and Noori, 2018). The highest mean AUDPC value was shown by the genotypes Basmati and Radha-13 and the lowest by Kathe Jhinuwa, Radha-4 and Sabitri. Similar variation in the response of rice genotypes to brown spot disease was also reported by Hossain and Kulkarni (2001). Padmanabhan and Ganguly (1954) reported that multiple foci of infection, prolonged period of favorable environmental conditions and host susceptibility results in epiphytotic conditions.
Under natural epiphytotic conditions, three genotypes Basmati (260.65), Radha-13 (172.80), Tilki (161.36) and Sunaulo Sugandha (155.35) were even more susceptible than the susceptible check genotype Sawa Mansuli (153.70). It may be due to the association with compatible races of $B$. oryzae and also due to high inoculum pressure. Radha-4 (88.88) showed better resistance against the pathogen than Sabitri (91.42). Devkota (2014) and Pantha et al. (2017) had reported Sabitri as resistant genotype and Sawa Mansuli as susceptible genotype.

Final disease severity, grain yield and thousand grain weight.

Maximum grain yield, and lowest disease severity rate were recorded in Sarju-52 (4.32 t/ha) and Sabitri (4.19 t/ha) however, Tilki (0.46 t/ha) and Basmati (0.96 t/ha) had the lowest grain yield with the highest disease severity rate while Radha-13 had grain yield similar to resistant genotype Sabitri, though it had the highest disease severity rate. Gangopadhyay and Chattopadhyay (1976) reported high yielding genotypes were less 
susceptible to brown leaf spot of rice which was found applicable in case of Sarju-52 and Sabitri but the contrast result was found in Radha-13, which suggests that, there may be some genetic potential for maximum grain yield in spite of having the highest disease severity and AUDPC value.

Among the 20 screened genotypes, farmers could utilize the Kathe Jhinuwa, Radha-4, and Sabitri showing resistance against brown spot disease in reference to the disease severity and yield as sources of resistance for breeding and for cultivation. Although the genotypes like Radha-13 and Hardinath-3 had higher disease severity, their grain yield was similar to the high yielder, Sarju-52 and to the resistant genotype, Sabitri. These did not show considerable yield loss which can be regarded as a tolerant genotype of rice towards the brown spot disease.

\section{RESUME}

Dhungana A., Puri C., Shah K., Yogi S., Dhakal D.P., Acharya B., Shrestha J. 2020. Criblage de génotypes de riz la pour résistance à l'helminthosporiose (maladie des taches brunes). Tunisian Journal of Plant Protection 15 (2): 29-39.

Une expérience au champ a été réalisée pour cribler 20 génotypes de riz contre l'helminthosporiose (maladie des taches brunes) causée par Bipolaris oryzae dans des conditions épiphytiques naturelles au champ à Bangaun, Dang, Népal, entre Juin 2018 et Mars 2019. L'expérience a été conduite en blocs aléatoires complets avec 3 réplications. Sawa Mansuli était pris comme génotype témoin sensible et Sabitri comme génotype témoin résistant dans l'expérience. L'évaluation de la maladie était effectuée en calculant la sévérité de la maladie et l'aire sous la courbe de progression de la maladie (AUDPC). Entre les génotypes de riz testés, la sévérité de la maladie et l'AUDPC variaient. Ces génotypes ont montré des réactions de résistant à hautement sensible sur la base des valeurs de l'AUDPC qui se situaient entre 88.51 à 260.65. La valeur moyenne la plus élevée de l'AUDPC a été obtenu avec Basmati (260.65) suivi par Radha-13 (172.80) et la moins élevée avec Kathe Jhinuwa (88.51). Egalement, le niveau de sévérité le plus élevé était enregistré avec Basmati (25.91\%) suivi par Radha-13 (21.00\%) et Tilki (20.75\%) et le moins élevé avec Kathe Jhinuwa (11.03\%) qui était au même niveau que Radha-4 (11.11\%) suivi par Sukhadhan-1 (12.02\%) et Sabitri (12.06\%). Le rendement en grains le plus élevé a été obtenu avec Sarju-52 (4.32 t/ha) suivi par Sabitri (4.19 t/ha). Ce rendement était négativement corrélé avec la moyenne de l'AUDPC par $14.77 \%$. Kathe Jhinuwa, Radha-4 et Sabitri peuvent être cultivés pour des obtenir de hauts rendements en grains sous des conditions de champ similaires et peuvent aussi être utilisés comme source de résistance d'un programme d'amélioration génétique.

Mots clés: AUDPC, Bipolaris oryzae, helminthosporiose, Oryza sativa, rendement en grains, résistance aux maladies, sévérité

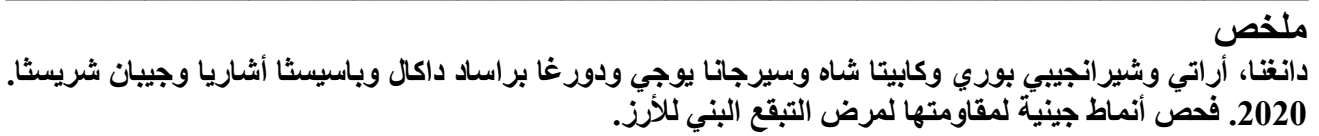

Tunisian Journal of Plant Protection 15 (2): 29-39.

تم في تجربة حقلية فحص 20 نمط جيني من الأرز ضد مرض التية التبقع البني الناتج عن الفطر Bipolaris oryzae تحت ظروف

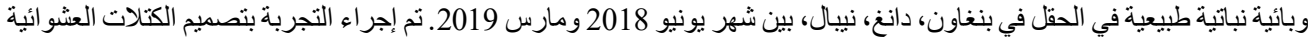

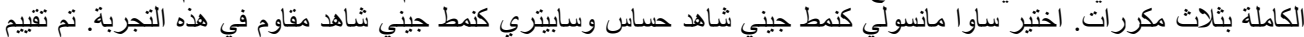
مستوى المرض باحتساب شدة الإصابة وكذللك المساحة تحت منحنى تقدم المرض (AUDPC). بين التقييم اختلاف في شدة الإصابة و 


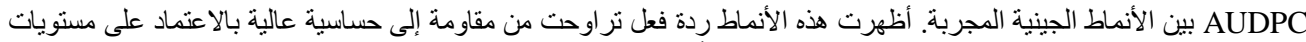
AUDPC

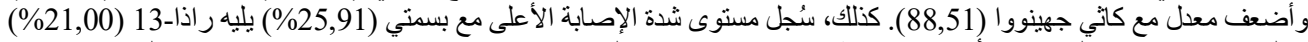

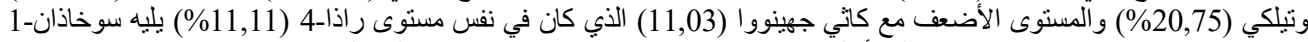
(12,02\%) وسابيتري (12,06\%). سُجلت أعلى إنتاجية حب مع سارجو-52 (4,32 طن/هك) يليه سابيتري (4, (4,19).

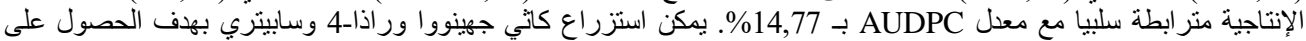
إنتاجيات حب عالية في ظروف حقلية مثابهة أو استعمالها كمصدر مقاومة في برنأمج تحسين ور وراني.

كلمات مفتاحية: إنتاجية حب، التبقع البني، شدة الإصابة، مقاومة الأمر اض، Oryza sativa، Bipolaris oryzae ،

\section{LITERATURE CITED}

Al-Maaroof, E.M. and Nori, A.M. 2018. Yellow rust development on different wheat genotypes. Second International Conference of Agricultural Sciences. Journal of Zankoy Sulaimani, Part-A, Special issue: 177-188.

Aryal, L., Bhattarai, G., Subedi, A., Subedi, M., Subedi, B., and Sah, G.K. 2016. Response of Rice Varieties to Brown Spot Disease of Rice at Paklihawa, Rupandehi. Global Journal of Biology, Agriculture and Health Sciences 5(2): 50-54.

Chattopadhyay, S.B., Chakravarti, N.K., and Ghose, A.K. 1975. Estimation of loss in yield of rice due to infection of brown spot incited by Helminthosporium oryzae. Phytopathol. 50: 434-438.

Das, M.K., Rajaram, S., Mundt, C.C., and Kronstad, W.E. 1992. Inheritance of slow-rusting resistance to leaf rust in wheat. Crop Science 32 (6): 1452-1456.

Devkota, M. 2014. Response of seeding dates and rice varieties to brown spot disease in Chitwan, Nepal. Master Thesis, Institute of Agriculture and Animal Science, Tribhuvan University, Rampur, Chitwan, Nepal, 50 pp.

Duveiller, E., Kandel, Y.R., Sharma, R.C., and Shrestha, S.M. 2005. Epidemiology of foliar blights (spot blotch and tan spot) of wheat in the plains bordering the Himalayas. Phytopathology 95 (3): 248-256. <DOI: 10.1094/PHYTO-95-0248>

Galanihe, L.D., Priyantha, M.G.D.L., Yapa, D.R., Bandara, H.M.S., and Ranasinghe, J.A.D.A.R. 2004. Insect pest disease incidences of exotic hybrids chili pepper varieties grown in the low country dry zone of Sri Lanka. Annals of Sri Lanka 6: 99-106. <DOI: 10.7726/ ajast.2014.1004>

Gangopadhyay, S., and Chattopadhyay, S.B. 1976. Carotenoids in the resistance of rice leaves to brown spot. Indian Phytopathology 29: 86-87.

Gomez, K.A., and Gomez, A.A. 1984. Statistical procedures for agricultural research. John Wiley and Sons Inc.

Haq, I.M., Adnan, M.F., Jamil, F.F., and Rehman, A. 2002. Screening of rice germplasm against
Pyricularia oryzae and evaluation of various fungitoxicants for control of disease. Pakistan Journal of Phytopathology 14 (1): 32-5.

Hossain, M.M., and Kulkami, S. 2001. Field evaluation of fungicides, neem-based formulations and biological agents against blast of rice. Journal of Maharashtra Agricultural Universities 26 (1-3): 148-150.

IRRI. 2002. International Rice Research Institute. Standard evaluation system for rice. International Rice Research Institute. Philippines, 56 pp.

Katasntones, G., Koutrovbas, S.D., Ntanos, D.A., and Lupoho, E. 2007. A comparison of three experimental designs for the field assessment of resistance to rice brown leaf spot of rice disease (Bipolaris oryzae). Journal of Phytopathology 155: 204-210.

Magar, P.B. 2015. Screening of Rice Varieties against Brown Leaf Spot Disease at Jyotinagar, Chitwan, Nepal. International Journal of Applied Sciences and Biotechnology 3 (1): 5660. <DOI: 10.3126/ijasbt.v3i1.12014>

Mew, T.W., and Gonzales. 2002. A handbook of rice seed- borne fungi. International rice research institute, Los Banos, Phillipines, 83 pp.

Padmanabhan, S.Y., and Ganguly, D. 1954. Relation between the age of rice plant and its susceptibility to Helminthosporium and blast diseases. Pages 44-50. In: Proceeding of the Indian Academy of Sciences, Section B 39 (2): 44-50, India

Pantha, P., Shrestha, S.M., Manandhar, H.K., Gaire, S.P., Aryal, L., and Yadav, D.R. 2017. Evaluation of rice genotypes for resistance against brown spot disease caused by Bipolaris oryzae. International Journal of Current Research 9 (04): 48562-48569.

Reddy, C.S., Laha, G.S., Prasad, M.S., Krishnaveni, D., Castilla, N.P., Nelson, A., and Savary, S. 2010. Characterizing multiple linkages between individual diseases, crop health syndromes, germplasm deployment and rice production situations in India. Field Crops Research 120: 241-253. <DOI: 10.1016/j.fcr.2010.10.005> 
Savary, S., Castilla, N.P., Elazegui, F.A., and Teng, P.S. 2005. Multiple effects of two drivers of agricultural change, labour shortage and water scarcity, on rice pest profiles in tropical Asia. Field Crops Res. 91: 263-271

Shrestha, J., Subedi, S., Timsina, K.P., Gairhe, S., Kandel, M., and Subedi, M. 2019. Maize Research. New India Publishing Agency (NIPA), New Delhi-34, India, 229 pp.
Shrestha, J., Singh Kushwaha, U.K., Maharjan, B., Subedi, S.R., Kandel, M., Poudel, A.P., and Yadav, R.P. 2020. Genotype $\times$ environment interaction and grain yield stability in Chinese hybrid rice. Ruhuna Journal of Science 11 (1): 47-58.

Zadoks, J.C. 2002. Fifty years of crop protection, 1950-2000. Netherlands Journal Agricultural Science 50 (2):181-193. 
